\title{
THE ROLE OF SOCIAL POLICY IN ECONOMIC DEVELOPMENT
}

\author{
Venelin Terziev \\ Academician of the Russian Academy of Natural History, Moscow, Russia, \\ Prof. D.Sc. (Ec.), D.Sc. (National Security), D.Sc. (Social Activities), Ph.D., National Military \\ University, Veliko Tarnovo, Bulgaria; University of Rousse, Rousse, Bulgaria, terziev@skmat.com
}

\begin{abstract}
Social policy is to a certain extent a philosophy, ideology, program to impact on demographics, employment of the population, standard, lifestyle and quality of life of the population, its income level and structure of consumption of material and cultural wealth, pension and other forms of social security, social services of the population as well as provision of a targeted state aid to the most unprotected, vulnerable and poor parts of the population. This system also includes the measures aimed at creating conditions for self-defense in order to maintain and improve the level of well-being of their families. If the enterprises and companies have good prospects for their own development, they will be able to pay stable salaries, to keep jobs, to solve many other issues.
\end{abstract}

Keywords: social policy, economic development, regulation, labor market.

\section{INTRODUCTION}

An important feature of the contemporary national projects of priority is their clear focus on the social field, i.e. on the person. The problems associated with investment in the person and improving the quality of life have never been paid so much attention before. The innovative approach to the habitual social sphere is the main difference of contemporary social, compared to all previously conducted projects at a national level. The effectiveness of the implementation of the social policy at any level (national, regional, corporate), dependents unconditionally on the financial capacity of those who planned it and implemented it (the state, municipality, company). The financing of a certain field depends directly on the solution of the problem related to the production development. It is namely this question that unveils the problems of formation of the revenue of the budgets, the deficit of finance and money, including for the implementation of the social policy as well. In case of lack of funds we cannot speak neither of the development of education, culture, health, nor of labor market and social protection of the population. All problems within the social sphere arise primarily due to lack of funds and are often associated with economic problems and errors in the formation of the expenditure of the budgets. By the way, the social policy itself and its basis - the socio-labor sphere, as evidenced by the practice, have a strong impact on the economic growth, financial flows and budgetary policy. 


\section{THEORETICAL BASIS OF SOCIAL POLICY AND THE REGULATION OF LABOR MARKET}

The content of the social policy can be successfully introduced by an explanation of the main structural elements of the social policy and its operational concepts.

Social policy is to a certain extent a philosophy, ideology, program to impact on demographics, employment of the population, standard, lifestyle and quality of life of the population, its income level and structure of consumption of material and cultural wealth, pension and other forms of social security, social services of the population as well as provision of a targeted state aid to the most unprotected, vulnerable and poor parts of the population. This system also includes the measures aimed at creating conditions for self-defense in order to maintain and improve the level of well-being of their families. If the enterprises and companies have good prospects for their own development, they will be able to pay stable salaries, to keep jobs, to solve many other issues (Georgiev, 2016; Georgiev, 2017-a; Terziev, Kanev, 2019; Terziev, 2019a-k).

Today the social responsibility of business is widely discussed. Moreover, everybody has to define the meaning of this in their own way. Meanwhile, in other countries this is a concept that is understood by itself, inciting every entrepreneur to think not only about their own benefit but also about society in which they live and work. By "obligations of business" is also often understood additional social responsibility beyond the regular requirements. In a way - additional burden. Sometimes, however, this burden comes simply from financial, economic, investment objectives of some companies. In particular, from the concern about the territory on which the company operates. If the scope of activity of an enterprise (company) is related to the formation of a city or is of structural importance, it cannot go without sponsoring kindergartens, schools, hospitals etc. Municipalities do not have sufficient funds to support this infrastructure, and the enterprises, which employ the residents of a town/village, cannot leave people to the mercy of fate. Alone, without the help of their enterprises, they will not be able to provide education for their children, to receive medical help, etc. and the enterprises have no choice but to invest money in this social infrastructure.

As we know, today there is a deficit of labor force everywhere. At the same time, the companies need to cut actively „harmful“, low-paid unskilled jobs. Moreover, they themselves train qualified specialists for new jobs, deal with the system for vocational training and retraining.

The social security is a comprehensive system of economic, legal and social rights and freedoms regulated by laws; social guarantees for citizens, providing the population with guaranteed level of security and life activity. Under the conditions of transition to a market economy, as well as after this period, it is of essential importance to establish the rights and social guarantees within the population employment field, the protection of vulnerable groups and their provision with an income not lower than the corresponding subsistence minimum, the prevention of decrease of the actual standard of living (real income of the population) in relation to price increase.

Social protection is a system of priorities and mechanisms for implementation of establishment of social, legal and economic guarantees for citizens in the legislation; a system of management bodies of other institutions at all levels, as well as a system of social services that provide a certain level of social protection, reaching a socially acceptable standard of living for the population in accordance with the specific conditions of social development. The system of social protection of the population, created in Bulgaria, includes measures aimed at establishing a minimum level of remunerations, pensions and scholarships; introduction of a national system of aid for children, support for large families, differentiation in the level of remuneration of different categories of workers in the budgetary sphere etc.

Social support is a system of measures to assist certain groups of able-bodied citizens who are temporarily in a difficult economic situation (partially or entirely unemployed, young people, etc.). by providing the necessary information, funds, loans, training and retraining, legal protection and implementation of other privileges.

Social self-protection of the population is the development of entrepreneurial and employment initiative, increasing the activity of the citizens and their organizations to improve the conditions of life.

Social assistance is a system of measures to help individual persons or groups who are actually in need to overcome or mitigate the difficulties of life, to maintain their social status and complete life activity, to adapt to society.

The main types and forms of social assistance are established at local (municipal) level, taking into account the economic circumstances and the factor of social need of the citizens. They include:

- Financial aid: one-off aid; aid for payment of transport services; assistance in extreme situations which 
resulted in large one-off losses (fire, flood, etc.);

- Social security benefits in natural form: providing necessities (food, shoes, clothes, etc.); repairs of homes, vehicles; distribution of drugs; provision of free food; provision of fuel;

- Humanitarian aid;

- Services and privileges: sending to rehabilitation centers, social and psychological assistance centers, homes and accommodation centers, etc.;

- Legal aid (protection of rights and interests, defense in court, etc.);

- Psychological support;

- Professional orientation (vocational rehabilitation assistance, advice on career choice);

- Information support, etc.

The basic principles of social assistance are: addressing, security, differentiated approach in determining the citizens in need, the size and type of aid, complexity, social reaction - review of social norms with respect to increasing the standard of living, independence of territorial authorities in determining the forms and levels of social assistance, as well as the determining the categories of citizens who need this assistance (Terziev, 2018-d; Terziev, Georgiev, 2018e-f; Terziev, Arabska, 2014; Terziev, 2015-b; Terziev, Arabska, 2016a).

Criteria for providing social assistance could be:

- The combined family income or average income of a person which is lower than the sum of the established subsistence minimum at national level for each family member by socio-demographic groups or equal to the relevant amount of the established subsistence minimum (lower than the minimum monthly wage, minimum pension, etc.).

- Lack of means of subsistence; loneliness and inability for self-service;

- Material damages or physical damages that resulted from natural disasters, catastrophes, national conflicts, as well as performance of official duties, etc.

Based on these criteria a database is created in the different municipalities and administrative districts comprising information on persons in need of targeted aid - a file that contains detailed information for citizens in need.

Social development is a process of change in society, expressed in changes in its structure, including the major classes, groups, layers, and social relations, i.e. changes in relationships between people as representatives of social groups in respect to their social status, their way of life.

Social norm is scientifically justified, calculated value or parameter setting the quantitative measure or level of development of the social process.

Way of life is a particular system of sustainable and reiterating forms of life activity and the methods of their organization, which have an internal unity.

Quality of life characterizes the quality aspect of meeting the material and cultural needs of the people by comparing their actual level with the selected standard of living.

Standard of living - this is to provide the population with the necessary for life material, spiritual, cultural and social consumer goods and the degree of satisfaction of the people with these goods. Along with the quality of life, the standard of living is among the most important conditions for the lifestyle. The standard of living is expressed in the quantity and quality of the consumed by a person commodities and services, starting from the "primary" that meet the needs of food, housing, clothing, means of transport, means to maintain health, etc., and reaching to the most complex, "high" needs related to satisfaction of spiritual, moral, aesthetic aspirations. The term "standard of living" is broader than such indicators as income growth and production of consumer goods.

Socio-demographic indicators of the standard of living:

- Fertility, mortality, population growth, average life expectancy, expected life expectancy, etc.;

- Indicators characterizing the condition and protection of the environment;

- Indicators and standards for social services and social security of the population. 
Generalized value indicators for the standard of living of the population.

Solvent demand by the population - demand for material goods and services, secured by finances. The volume and structure of the solvent demand are determined by the volume of cash incomes of the population and received loans, from which the mandatory payments (taxes, repayment of loans, insurance, etc.) are deducted; by their distribution among the different groups of the population in accordance with the social, professional and demographic structure of society; by the level of education and culture of the population; by the level of retail prices and service charges, as well as by their correlation with other factors.

Needs of the population - a combination of material needs (food, housing, household items, etc.), cultural, spiritual and social needs (education, meeting of cultural needs, leisure needs, etc.), vital goods which need to be met.

Real income (excluding services) - part of the national income, used by the population to meet its material, cultural and spiritual needs.

Real income (including services) - part of the gross national product used by the population for consumption and accumulation of material goods and services.

In order to characterize the increase (decrease) in the real income, indexes of real income of the population are calculated, as well as indexes of real income in terms of social groups.

Incomes of the population - the amount of funds received by the population from different sources, in the form of cash and natural receipts, free services and discounted services (in the unpaid part of them).

Cash household income - this is the sum of cash in the household in the form of salaries, pensions, scholarships, benefits, entrepreneurial income, interest, dividends and other income from property, real estate, stocks and bonds, funds from the sale of products from personal subsidiary economy.

Aggregate income - in statistical practice, this is one of the main indicators of standard of living for the material security of the population and includes all types of cash income. It also includes the value of the natural proceeds received from the personal subsidiary economy and used for private (domestic) consumption.

Both cash and aggregate income can be total - to the payment of taxes and mandatory payments (gross), and disposable - after the said payments (net). Disposable income is the maximum amount of money that a household can spend on final consumption of goods and services without using savings and other sources.

Average income per household member - aggregate household income (salaries, pensions, scholarships, benefits, income from entrepreneurial activity and personal subsidiary economy, income from other sources), calculated for a month or a year for each household member. When calculating the average income per household member citizens that live together are taken into account and able-bodied unemployed members who are not registered in labor offices, as well as children and adolescents who are fully insured by the state, are excluded.

Minimum consumer budget - a range of consumer goods and services in natural and value form that meets the requirements of the relevant science-based standards and regulations and is officially recognized by the public as acceptable at the present stage of its economic development.

Minimum consumer budget (budget of the consumer minimum) - it is expressed in a value assessment of consumer goods and services to satisfy basic physiological and socio-cultural needs of workers and their families at a level of development of the country.

Subsistence minimum - a socio-economic category, characterizing the combination of the minimum volume of material goods and services in a given ratio, necessary and sufficient to secure the health and maintenance of vital activity of the employed person and their family, to reimburse lost labor force and to secure continuation of the family.

Index of the impact of prices on the limits of subsistence minimums - a relative indicator, characterizing changes in the limits of the subsistence minimum during the current and base period.

Social layers - social communities, distinguished in society by one or several related qualities of its differentiation: income, prestige, level of education, culture, residence, participation in the exercise of power, etc. Many of the social layers are formed at the intersection of different types of structures: socioprofessional, qualification, educational, etc.

Middle layers - classes and social groups occupying an intermediate position between the two poles in society. 
Social structure of society - the relationship between the social groups. Types of social structures: sociodemographic, socio-professional, national-ethnic.

The socio-demographic structure is the relationship between elements such as gender, age, marital status.

The Socio-professional structure unites people by professional characteristics and by occupied position professions associated with highly qualified, creative and intellectual work, etc.

Social class structure - distinguishes classes and social groups by the following criteria: relation to the means of production; role in the social organization of labor; amount and source of the received part of the public wealth.

National-ethnic structure - relationship between nations, nationalities, clans, tribes, national and ethnic groups.

Social stratification - structuring of inequality between different social groups.

Social guarantees - conditions and means of providing the citizens with the opportunity to use their state given by law socio-economic, political and personal civil rights and freedoms. The reliability of the social guarantees determines the degree of implementation of the rights and freedoms provided. The main law of the state (the Constitution) and regulations indicate the specific mechanisms for actual implementation of social guarantees.

Social priorities - social tasks, which are recognized by society at a given stage of its development as urgent, requiring a decision of major importance.

Level of low security (poverty line) - cash income amount needed to cover the cost of acquiring the consumer goods and services, necessary for the individual and their family. It is measured using the subsistence minimum or other indicators (minimum wage, etc.).

Social rehabilitation - this is a process aimed at recovering of social life activity of the individual, which has been limited by age or due to other reasons.

Social security - a system established by the state to secure the citizens in case of retirement, full or partial disability, loss of a person who supports the family, as well as benefits for large and poor families.

Unemployed - an able-bodied citizen, who has no income from work or other legitimate source due to reasons beyond their control, registered in the employment office, looking for work, willing and ready to work, and ready to finish a training course if necessary.

Temporary unemployment benefits - a state compensation to citizens under certain conditions: loss of work in enterprises, institutions and organizations, as well as for those who seek to begin work again after a long break.

Public paid job - activities organized by the authorities for providing temporary employment of citizens who have lost their jobs and are looking for work, primarily from socially unprotected groups.

Labor market - a sphere of socio-economic and legal relations created in connection with the demand and supply of labor force, when connecting the personal and material factors of labor.

Refugees - persons with different nationalities, who have entered or are willing to enter the territory of another country.

Homeless - a person without a certain place of residence and profession.

To summarize, we can draw the conclusion that the content of the social policy is a program of specific actions of public authorities and non-state institutions, public associations in the implementation of tactical and strategic tasks aiming at harmonization of the public relations.

The social policy has a number of important features that can be classified by different characteristics (Table 1.).

Now strategies for socio-economic development are being developed for following longer periods. The social policy has changed radically its instruments due to the development of a legislative base oriented towards joint activities of government and business. Thus the essence of the social policy is expressed in its strategy and tactics in the activities of the state directed towards satisfaction of material and cultural needs of society, towards provision of necessary assistance primarily to those who need it most, feasible on the basis of the principles of justice and identification of recipients. 
Table 1. Classification of the social policy

\begin{tabular}{|l|l|}
\hline \multicolumn{1}{|c|}{ Characteristics } & \multicolumn{1}{c|}{ Characteristics of the social policy } \\
\hline $\begin{array}{l}\text { Level of development and } \\
\text { implementation of the social } \\
\text { policy }\end{array}$ & $\begin{array}{l}\text { State social policy } \\
\text { Regional social policy } \\
\text { Public social policy } \\
\text { Social policy of the company, organization, establishment }\end{array}$ \\
\hline $\begin{array}{l}\text { Contents of the activities, tasks of } \\
\text { the social policy }\end{array}$ & $\begin{array}{l}\text { Organizational, legal, social, economic, financial, } \\
\text { environmental, demographic, ideological, propagandistic, } \\
\text { socio-cultural }\end{array}$ \\
\hline $\begin{array}{l}\text { Period of implementation of the } \\
\text { social policy }\end{array}$ & $\begin{array}{l}\text { Long-term } \\
\text { Medium-term } \\
\text { Short-term } \\
\text { Current }\end{array}$ \\
\hline Efficiency - inefficiency & $\begin{array}{l}\text { Effective - effective, efficient, pragmatic, implemented to a } \\
\text { considerable extent, comprehensible for the population } \\
\text { Ineffective - unreal, "on paper", unimplemented to a } \\
\text { considerable extent, incomprehensible to the population }\end{array}$ \\
\hline
\end{tabular}

Undoubtedly, social policy and social-labor sphere are in a constant process of development. Moreover, social policy requires substantial financial resources and has a strong impact on the development of the national economy, economic growth, the dynamics of gross domestic product (GDP), the movement of society and progress. It is obvious that without a well-developed system of education, culture, health, etc., the development of production is impossible, as it is namely these factors that have a huge impact on people as the main (personal) factor of production. As an example of the opposite influence of social policy and social-labor sphere on the economy, we can consider the functioning of the pension system. The state and employers spend huge resources for development and implementation of the pension system. On the one hand, this can be regarded as a purely social measure, which is not related to economic indicators: the pensioner does not work, does not produce output, does not participate in the creation of the GDP, etc. On the other hand, if the pension system is created from the perspective of social justice, if the amount of the pension depends directly on the performance and quality of work of the pensioner in the past, this system will also encourage the labor productivity and the production development as a whole. Similar interconnection exists between the economic efficiency and the solution of the employment problem, labor protection, social security, development of culture, health, science and education (Terziev, Arabska, 2014; Terziev, 2015-b; Terziev, Arabska, 2016a).

We can distinguish several stages in the development of social policy:

First stage - sharp contraction of the social policy (early and mid-90-s) - the maximum contraction of nonprofile assets is accepted by companies with different forms of property as a condition for the survival of the company. Two-thirds of the objects of social infrastructure are transferred to the municipalities, as this has all the elements of spontaneity and not high degree of control.

Second stage - stabilization of the social infrastructure (1997 / 1998-2000) - the approach to social objects becomes more differentiated.

Third stage - economic upturn (transition of enterprises from stage of survival to stage of development) optimization of the social infrastructure.

\section{CONCLUSION}

Today, an optimization of social infrastructure can be achieved primarily at the enterprise level. In the first place, because at a micro level, the social problems occur most acute (employees' needs for housing, medical services, the relevant cultural and educational environment, etc.). In the second place, the company 
is interested that its employees are healthy, able-bodied, educated. In the third place, each company in a market economy aims at gaining profit, which may not always be in the form of money (but in status, in obtaining credit of trust by the public, by the local administration, that allows it to fully implement its strategic objectives, both commercial and non-commercial). Thus the economy and social policy are organically connected, which requires regular and moderate choice of priorities for their coordinated development both at national and regional and local level (Terziev, 2015-b).

\section{REFERENCE LIST}

Georgiev, Marin. (2016). Obshtestvenoto i ikonomichesko razvitie v konteksta na sotsialnite politiki. // Spisanie za nauka „Novo znanie“. Visshe Uchilishte po Agrobiznes i Razvitie na Regionite, 5, 2016, N 4, str. 26-41, ISSN 2367-4598 (Online), (Print) ISSN $1314-5703$ (Георгиев, Марин. Общественото и икономическо развитие в контекста на социалните политики. // Списание за наука „Ново знание“. Висше училище по агробизнес и развитие на регионите, 5, 2016, N 4, стр. 26-41, ISSN 2367-4598 (Online), (Print) ISSN 1314-5703.

Georgiev, Marin. (2017). Sbalansirovannaya karta kak alyternativa malogo biznesa. // Innovatsionnie tehnologii v nauke novogo vrmeni, Sbornik statey Mezhdunarodnoy nauchno - prakticheskoy konferentsii 1 fevralya 2017 g., Ufa NITS AETERNA, Chasty 1, 2017, s. 43-49, ISBN 978-5-00109004-5, ISBN 978-5-00109-007-6 (Георгиев, Марин. Сбалансированная карта как альтернатива малого бизнеса. // Инновационніе технологии в науке нового врмени, Сборник статей Международной научно - практической конференции 1 февраля 2017 г., Уфа НИЦ АЭТЕРНА, Часть 1, 2017, с. 43-49, ISBN 978-5-00109-004-5, ISBN 978-5-00109-007-6).

Georgiev, Marin. (2017a). Impacts of active social programs on labor market. // Mezhdunarodnayy nauchnayy zhurnal «Innovatsionnaya nauka». NITS Aeterna, N 02-1, 2017, pp. 139-143, ISSN $2410-$ 6070 (Georgiev, Marin. Impacts of active social programs on labor market. // Международный научный журнал «Инновационная наука». НИЦ Аэтерна, N 02-1, 2017, pp. 139-143, ISSN 2410 6070).

Terziev, V., Kanev, D. (2019). Modern developments in behavioral economics. // Smart Technologies and Innovations in Design for Control of Technological Processes and Objects: Economy and Production Proceeding of the International Science and Technology Conference "FarEastCon-2018" Volume 138, October 2-4, 2018, Vladivostok, Russian Federation, pp. 10-23, 2019, (Print) ISBN978-3-030-15576-6, (Online) ISBN978-3-030-15577-3.

Terziev, Venelin. (2019a). Provision of integrated employment and social assistance services in Bulgaria. // Smart Technologies and Innovations in Design for Control of Technological Processes and Objects: Economy and Production Proceeding of the International Science and Technology Conference „FarEastCon-2018“ Volume 138, October 2-4, 2018, Vladivostok, Russian Federation, pp. 24-39, 2019, (Print) ISBN978-3-030-15576-6, (Online) ISBN978-3-030-15577-3.

Terziev, Venelin. (2019b). Problems of control in the social sphere. // INTCESS 2019- $6^{\text {th }}$ International Conference on Education and Social Sciences, 4-6 February, 2019, Dubai, International Organization Center of Academic Research, Istanbul, Turkey, pp. 577-593, ISBN: 978-605-82433-5-4.

Terziev, Venelin. (2019c). The criterion "competence" in the economic sector. // INTCESS 2019- $6^{\text {th }}$ International Conference on Education and Social Sciences, 4-6 February, 2019, Dubai, International Organization Center of Academic Research, Istanbul, Turkey, pp. 1241-1247, ISBN: 978-605-824335-4.

Terziev, Venelin. (2019d). Social policy and labor market development in Bulgarian transition period. // INTCESS 2019- 6th International Conference on Education and Social Sciences, 4-6 February, 2019, Dubai, International Organization Center of Academic Research, Istanbul, Turkey, pp. 703-714, ISBN: 978-605-82433-5-4.

Terziev, Venelin. (2019e). Theoretical basis of development of labor market and social policy in the republic of Bulgaria. // INTCESS 2019- $6^{\text {th }}$ International Conference on Education and Social Sciences, 4-6 February, 2019, Dubai, International Organization Center of Academic Research, Istanbul, Turkey, pp. 715-726, ISBN: 978-605-82433-5-4. 
IJASOS- International E-Journal of Advances in Social Sciences, Vol. V, Issue 14, August 2019

Terziev, Venelin. (2019f). The problem of social efficiency- Indicators for social efficiency. // INTCESS 20196th International Conference on Education and Social Sciences, 4-6 February, 2019, Dubai, International Organization Center of Academic Research, Istanbul, Turkey, pp. 669-678, ISBN: 978605-82433-5-4.

Terziev, Venelin. (2019g). Experiencing social policy development and efficiency measurment. // INTCESS 2019- $6^{\text {th }}$ International Conference on Education and Social Sciences, 4-6 February, 2019, Dubai, International Organization Center of Academic Research, Istanbul, Turkey, pp. 679-686, ISBN: 978605-82433-5-4.

Terziev, Venelin. (2019h). Efficiency and assessment of social technology. // INTCESS 2019- $6^{\text {th }}$ International Conference on Education and Social Sciences, 4-6 February, 2019, Dubai, International Organization Center of Academic Research, Istanbul, Turkey, pp. 687-694, ISBN: 978-605-82433-5-4.

Terziev, Venelin. (2019i). Conceptual framework of social adaptation. // INTCESS 2019- $6^{\text {th }}$ International Conference on Education and Social Sciences, 4-6 February, 2019, Dubai, International Organization Center of Academic Research, Istanbul, Turkey, pp. 494-503, ISBN: 978-605-82433-5-4.

Terziev, Venelin. (2019j). The dependence social adaptation- socialization. // INTCESS 2019- $6^{\text {th }}$ International Conference on Education and Social Sciences, 4-6 February, 2019, Dubai, International Organization Center of Academic Research, Istanbul, Turkey, pp. 478-485, ISBN: 978-605-82433-5-4.

Terziev, Venelin. (2019k). Social activity and human resources as social development factors. // INTCESS 2019- $6^{\text {th }}$ International Conference on Education and Social Sciences, 4-6 February, 2019, Dubai, International Organization Center of Academic Research, Istanbul, Turkey, pp. 546-553, ISBN: 978605-82433-5-4.

Terziev, Venelin. (2018). The active model of a social programme and its strategic advantage . // ADVED 2018- $4^{\text {th }}$ International Conference on Advances in Education and Social Sciences Abstracts \& Proceedings, 15-17 October 2018- Istanbul, Turkey, International Organization Center of Academic Research, www.ocerints.org, Istanbul, Turkey, 2018, pp. 189-203, ISBN: 978-605-82433-4-7.

Terziev, Venelin. (2018a). Active social programs development in Bulgaria: contemporary challenges and social management instruments. // ADVED 2018- $4^{\text {th }}$ International Conference on Advances in Education and Social Sciences Abstracts \& Proceedings, 15-17 October 2018- Istanbul, Turkey, International Organization Center of Academic Research, www.ocerints.org, Istanbul, Turkey, 2018, pp. 149-163, ISBN: 978-605-82433-4-7.

Terziev, Venelin. (2018b). Social assistance services and integrated employment in Bulgaria. // ADVED 2018- $4^{\text {th }}$ International Conference on Advances in Education and Social Sciences Abstracts \& Proceedings, 15-17 October 2018- Istanbul, Turkey, International Organization Center of Academic Research, www.ocerints.org, Istanbul, Turkey, 2018, pp. 164-177, ISBN: 978-605-82433-4-7.

Terziev, Venelin. (2018c). Impact of the labor market policies for ensuring employment. // ADVED 2018- $4^{\text {th }}$ International Conference on Advances in Education and Social Sciences Abstracts \& Proceedings, 1517 October 2018- Istanbul, Turkey, International Organization Center of Academic Research, www.ocerints.org, Istanbul, Turkey, 2018, pp. 178-188, ISBN: 978-605-82433-4-7.

Terziev, Venelin. (2018d). Importance of human resources to social development. // ADVED 2018- $4^{\text {th }}$ International Conference on Advances in Education and Social Sciences Abstracts \& Proceedings, 1517 October 2018- Istanbul, Turkey, International Organization Center of Academic Research, www.ocerints.org, Istanbul, Turkey, 2018, pp. 204-212, ISBN: 978-605-82433-4-7.

Terziev, V., Georgiev, M. (2018e). A strategic framework for the development of social entrepreneurship in Bulgaria. // Knowledge - International Journal, August 2018, Institute of Knowledge Management, Skopje, Macedonia, 25, 2018, N 1, pp. 23-34, ISSN 1857-923X (for e-version), ISSN 2545 - 4439 (for printed version).

Terziev, V., Georgiev, M. (2018f). Support for the development of social entrepreneurship in Bulgaria. // Knowledge - International Journal, September, 2018, Institute of Knowledge Management, Skopje, Macedonia, 26, 2018, N1, pp.57-74, ISSN 1857-923X (for e-version), ISSN 2545 - 4439 (for printed version).

Terziev, V., E., Arabska. (2014). Assessment of active social policies' impacts on labor market in the Republic of Bulgaria. Kolektivnaya monografiya "Sotsialyno-ekonomicheskie i pravovay razvitiya ekonomiki“, Ufa, Aeterna. Rossiya, 2014. ISBN 978-5-906769-97-8, str. 3-57 (Terziev, V., E. Arabska. 
(2014). Assessment of active social policies' impacts on labor market in the Republic of Bulgaria. Колективная монография „Социально-экономические и правовы развития экономики“, Уфа, Аэтерна. Россия, 2014. ISBN 978-5-906769-97-8, стр. 3-57).

Terziev, Venelin. (2015). Impact of active social policies and programs in the period of active economic transformations in Bulgaria, „East West” Association for Advanced Studies and Higher Education,Vienna, 2015, ISBN 78-3-903063-44-0, 434 p.

Terziev, Venelin. (2015a). Assessment of active social policies impact of social policies on transformation processes in bulgarian economy, Moscow, 2015, Publisher „Перо“, 110 p.

Terziev, Venelin. (2015b). Opportunities for improving the efficiency of the social adaptation of servicemen discharged from military service in Bulgaria:- Novosibirsk: Publisher CRNS, 2015. ISBN 978-5-00068402-3, $270 \mathrm{p}$.

Terziev, V., E., Arabska. (2016a). Effektivnoe vliyanie na raynok truda posredstvom uluchsheniya realizatsii sotsialynoy politiki. Novosibirsk: Izdatelystvo TSRNS, 2016. ISBN 978-5-00068-496-2, 312 str (Терзиев, В., Е. Арабска. (2016а). Эффрективное влияние на рынок труда посредством улучшения реализации социальной политики. Новосибирск: Издательство ЦРНС, 2016. ISBN 978-5-00068-496-2, 312 стр). 